\title{
Medium- and large-sized mammal composition in the Chapada dos Veadeiros National Park and adjacent areas, state of Goiás, Brazil
}

\author{
Átilla Colombo Ferreguetti ${ }^{1,3}$; Isadora Cristina Motta Lessa ${ }^{2,4}$; Emerson Monteiro Vieira ${ }^{2,5}$; \\ André Almeida Cunha ${ }^{2,6}$ \& Helena Godoy Bergallo ${ }^{1,7}$
}

\footnotetext{
1 Universidade do Estado do Rio de Janeiro (UERJ), Instituto de Biologia Roberto Alcântara Gomes (IBRAG), Departamento de Ecologia (DECOL), Laboratório de Ecologia de Vertebrados. Rio de Janeiro, RJ, Brasil.

2 Universidade de Brasília (UNB), Instituto de Ciências Biológicas (IB), Departamento de Ecologia, Programa de Pós-Graduação em Ecologia. Brasília, DF, Brasil.

${ }^{3}$ ORCID: http://orcid.org/0000-0002-5139-8835. E-mail: atilla.ferreguetti@gmail.com (corresponding author)

${ }^{4}$ ORCID: http://orcid.org/0000-0002-4746-5185. E-mail: isadoracristinam@gmail.com

${ }^{5}$ ORCID: http://orcid.org/0000-0002-8691-342X.E-mail: emvieira@unb.br

${ }^{6}$ ORCID: http://orcid.org/0000-0002-4753-0178. E-mail: andrecunha@unb.br

7 ORCID: http://orcid.org/0000-0001-9771-965X.E-mail: nena.bergallo@gmail.com
}

\begin{abstract}
The Cerrado is the second largest Brazilian biome and only $2.8 \%$ is represented by protected areas. Considering the relevance of the Cerrado and Conservation Units in preserving the mammalian diversity, we provided the first assessment of the diversity of medium- and large-sized mammal species in the Chapada dos Veadeiros National Park (CVNP) and surroundings. We tested the effectiveness of the CVNP by assessing the difference in species composition within the park and its surroundings. We sampled CVNP in the rainy (October-December 2013) and dry seasons (March-June 2014) in order to characterize the seasonality within the community. We selected 36 sampling sites to evaluate the composition of the medium and large mammals in the CVNP and its surroundings, 18 in the CVNP and 18 in the park surroundings. We ordered mammalian composition and frequency of individuals data by using a Non-metric Multidimensional Scaling analysis (NMDS). We assessed the effect of season (dry and rainy seasons) and locality (within the CVNP and surroundings) on mammalian species richness with a two-way analysis of variance (Two-way ANOVA). We recorded 23 species, 13 within the CVNP and 17 species in its surroundings. Composition and frequency of records differed between dry and rainy seasons, with higher richness in the rainy season. Species' composition and the frequency of records were also different between within the CVNP and its surroundings, with higher richness in the surroundings. These results provide information for the increase of the knowledge of mammalian ecology but also is useful as a tool for future strategies to the conservation of these species. More attention should be given to the monitoring of these species in the long term because this area still harbor some viable populations.
\end{abstract}

Key-Words. Brazilian savannah; Camera-trap; Cerrado; Protected areas.

\section{INTRODUCTION}

The Cerrado is the second largest Brazilian biome, covering about 2 million $\mathrm{km}^{2}$ (approximately $24 \%$ of the country), presenting a heterogeneous mosaic of vegetation types that include natural grasslands, savanna and forest formations (Walter \& Ribeiro, 2008). Due to the advanced population growth and the economic demand, since 1970, Brazil has undergone a great expansion in the agroindustry, which resulted in the increase of lands for cultivation, pastures and for urban areas, resulting in the degradation of the Cerrado which already exceeded $55 \%$ of its natural area (Klink \& Machado, 2005). According to the features men- tioned above along with the high endemism this biome was included among the 34 hotspots in the world (Myers et al., 2000; Mittermeier et al., 2005; Noguera-Urbano \& Escalante, 2015). Of the entire territory covered by the Cerrado, only $2.8 \%$ is represented by areas protected by law (i.e., conservation units; Klink \& Machado, 2005).

Conservation Units in Brazil are areas protected by law and constitute natural environments. One of its functions is to guarantee the representativeness of significant samples of the different populations, habitats and ecosystems of the national territory (Freitas, 2009; Drummond et al., 2009). The effectiveness of these protected areas is affected by factors related to the configuration 
and structure of the landscape, loss of habitat, increase of human occupation, increase of human density, and invasion by exotic species (Le Saout et al., 2013; Lessa et al., 2016, 2017).

Brazil has a rich mammal fauna, consisting of 701 species, and is the richest country the world in terms of mammal species (Paglia et al., 2012). Of this total, 150 species of non-volant mammals occur in the Cerrado, representing the second most diverse group of terrestrial vertebrates in the biome (Aguiar et al., 2004; Paglia et al., 2012), with the high richness explained by the influence of other adjacent biomes, such as the Amazonia and the Atlantic Forest (Johnson et al., 1999; Costa, 2003). There are different factors, both abiotic as biotic that can determine the composition and abundance of mammals. Water resources availability, for example, can be a limiting factor for mammalian species because temporal environmental variation influences the structure and species composition (i.e., which species may occur) of a community (O'Connell, 1989; Goulart et al., 2009; Ferreguetti et al., 2017). Ecological studies with mammals confirm the importance of this group in protected areas, as they act on seed dispersal, herbivore control and nutrient cycling, especially larger mammals (Wilson \& Reeder, 2005; Galetti et al., 2015). Larger species have predominantly nocturnal habits, relatively large home ranges, and low population densities, and are therefore good indicators of environmental quality (Galetti et al., 2009; Ahumada et al., 2011).

Considering the relevance of the Cerrado and Conservation Units in preserving the mammalian diversity, we aimed to provide the first assessment of the diversity and composition of medium- and large-sized mammal species in the Chapada dos Veadeiros National Park (CVNP). This primary information is necessary and very important because it contributes to the knowledge about the distribution of mammals and are the first step to the establishment of species conservation strategies (Costa et al., 2005). We also aimed to test the effectiveness of the CVNP by assessing the difference in species composition within the park and its surroundings. We expect to find a higher species richness within the CVNP. In addition, we tested the influence of seasonality on the mammal community. Once that the Cerrado has two well-defined seasons, we expect to find a higher richness in the rainy season due to increased resources (water and food availability) in this season.

\section{MATERIAL AND METHODS}

\section{Study area}

We performed the study in the Chapada dos Veadeiros National Park (CVNP) and established a buffer zone (up to $10 \mathrm{~km}$ outside the park surroundings), called the surrounding zone (Fig. 1). The CVNP has an area of approximately 240,000 ha and is located in the northeast of the state of Goiás, between the municipalities of Alto Paraíso de Goiás, Cavalcante and Colinas do Sul and is

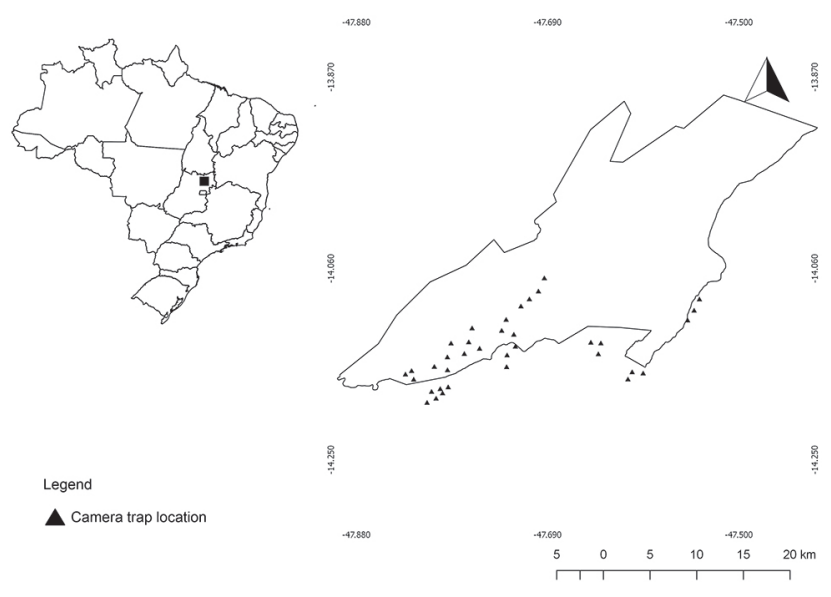

Figure 1. Distribution of camera-traps in the sampled area of Chapada dos Veadeiros National Park (delimited polygon) and its surroundings (10 km from the park boundaries), separated by at least $1 \mathrm{~km}$, in the Cerrado of central Brazil.

inserted within the Cerrado biome (coordinates of $13^{\circ} 51^{\prime}$ to $14^{\circ} 10^{\prime} \mathrm{S}$ and $47^{\circ} 25^{\prime}$ to $47^{\circ} 42^{\prime} \mathrm{W}$ ). The CVNP is considered the largest area of environmental conservation and the most important ecotourism attraction in the region (Barbosa, 2008). The Cerrado region is located in mid-latitudes and presents the main seasonal climatic type (Aw), with annual temperature between $24^{\circ} \mathrm{C}$ and $26^{\circ} \mathrm{C}$ and $90 \%$ of rainfall concentrated from October to April, while in the dry season (May to September), the air humidity is very low (below 20\% in August and September) and the amount of rainfall can reach zero millimeters in a few months (Marcuzzo et al., 2012). In the region of CVNP, there is a predominance of soils poor in nutrients, which ends up preventing the larger plant colonization, whichever the grasslands of the Cerrado Sensu Strictu (Eiten, 1972; Felfili et al., 2007). In total, the CVNP presents $77 \%$ of savanna formation, and $9 \%$ corresponds to the forest fragments (Porto et al., 2011). On the other hand, the surrounding of the park has the largest sum of private reserves (Private Reserves of Natural Heritage - RPPN) of the State of Goiás, are 21 RPPNs with 21,515.87 ha (30\% of CVNP area) and these are hold a higher percentage of forest cover (Falconi \& Diniz-Filho, 2003; Silva et al., 2016). $80 \%$ of the RPPNs area, located in the Alto Paraiso region, are protected near the areas sampled in this study (Silva et al., 2016).

\section{Data survey}

We sampled CVNP in the rainy season (October to December 2013, with an average rainfall of $354 \mathrm{~mm}$ ) and dry season (March to June 2014, with a mean rainfall of $4 \mathrm{~mm}$ ) in order to characterize the seasonality within the community. We selected 36 sampling sites, according to accessibility, to evaluate the composition of the medium and large mammals in the CVNP and its surroundings, 18 in the CVNP and 18 in the park surroundings (i.e., $10 \mathrm{~km}$ maximum buffer, Fig. 1). At each sampling site a camera-trap was installed (Model: Bushnell Trophy Cam HD) distant by at least $1 \mathrm{~km}$, installed $30 \mathrm{~cm}$ above the ground, and an area of $3 \mathrm{~m}^{2}$ in front of the camera 
was partially cleaned (i.e., removed from small shrubs, vines that could affect the visibility and motion sensor). Camera-traps were placed close to trails where we found evidence of use by medium-sized or large mammals and programmed to take pictures $24 \mathrm{~h}$ per day. We did not use any bait near the camera-traps to avoid attracting or drive away certain species. To obtain the sampling effort per site, we calculated the number of camera days that each individual camera functioned in the field by counting the number of days from when the camera was active to the date of the last picture taken. We considered a camera day as a period of $24 \mathrm{~h}$ during which the camera was operating, and we used each camera-trap as a sampling unit. The total sampling effort was obtained by adding the number of camera days that every camera operated in each site during all study period. We considered medium and large mammals, the species recorded with a camera-trap above $1 \mathrm{~kg}$ of mass, as reported in previous studies (Chiarello, 1999; Ferreguetti et al., 2017). We used field guides for species identification (Eisenberg \& Redford, 1999), we classify the endemic species according to Paglia et al. (2012). The species have also been classified in relation to the degree of threat according to the national and international lists of threatened fauna (ICMBio, 2018; IUCN, 2018).

\section{Data analysis}

The observed and estimated richness were represented by the rarefaction curve. The expected richness curve corresponds to the richness of each sample calculated by one of the estimators (Bootstrap, Chao 1, and Jackknife 1). We obtain the model with estimators with 1,000 randomizations using the software EstimateS 9.0 (Colwell, 2013). We used the frequency of individuals as input to perform the analysis.

We considered the frequency of individuals of each species at intervals of 1 hour apart to maintain independence between the processed photos in each camera-trap. We ordered the data obtained from camera-traps by using a non-metric multidimensional scaling (NMDS) with Bray-Curtis metric to evaluate the similarity in composition and frequency records of the species. We used this analysis to verify the existence of some pattern in the community ordering in the CVNP. We assessed the relationship between the season (dry and rainy seasons) and locality (within the CVNP and surrounding) on mammalian species richness with a two-way analysis of variance (Two-way ANOVA). These analyses were performed in SYSTAT $13^{\circledR}$ program.

\section{RESULTS}

We recorded, in a 2,230 camera-days effort, a total of 240 records (98 and 142, within the CVNP and in the surroundings, respectively) of 23 native mammal species, 13 species within the CVNP and 17 species in the surroundings of the park (Fig. 2, Table 1). In addition, we recorded the presence of two exotic species, Canis familiaris both within the CVNP and its surroundings, and Bos Taurus, with 51 records in the surrounding area of the park. The orders with the highest frequency of registrations were Carnivora, with $39.1 \%$, followed by Xenathra (17.3\%), Rodentia and Artiodactyla (both with 13\%). We recorded 10 exclusive species in the surrounding area of the CVNP and seven within the park (Table 1). Of the 23-species recorded in total, three species (Myrmecophaga tridactyla, Priodontes maximus and Tapirus terrestris) are listed in the Brazilian and IUCN threatened species, classified as Vulnerable. Chrysocyon brachyurus, Lycalopex vetulus, Puma yagouaroundi, Puma concolor, Panthera onca, and Ozotoceros bezoarticus are threatened in the Brazilian list of endangered species.

In the species rarefaction curve, the Chao 1 richness estimator showed the lowest standard deviation in relation to the observed richness and estimated a maximum average of 25 species in total (SD: 0.87$), 12$ species

Table 1. List of mammals recorded during the sampling with camera-traps in the 36 points within the Chapada do Veadeiros National Park (CVNP) and its surroundings. Endangered (EN), Vulnerable (VU) and Critically Endangered (CR) according to the list of IUCN (2018), and the National List of Brazil (BR) ICMBio (2018).

\begin{tabular}{|c|c|c|c|}
\hline Species & $\begin{array}{c}\text { Threatened } \\
\text { category }\end{array}$ & CVNP & Surroundings \\
\hline \multicolumn{4}{|l|}{ Didelphimorphia } \\
\hline Didelphis aurita (Wied-Neuwied, 1826) & & 0 & 11 \\
\hline \multicolumn{4}{|l|}{ Xenartha } \\
\hline Myrmecophaga tridactyla Linnaeus, 1758 & VUIUCN,BR & 9 & 3 \\
\hline Priodontes maximus (Kerr, 1792) & VUIUCN,BR & 7 & 0 \\
\hline Dasypus novemcinctus Linnaeus, 1758 & & 11 & 11 \\
\hline Euphractus sexcinctus (Linnaeus, 1758) & & 9 & 0 \\
\hline \multicolumn{4}{|l|}{ Primates } \\
\hline Sapajus nigritus Goldfuss, 1809 & & 0 & 12 \\
\hline \multicolumn{4}{|l|}{ Lagomorpha } \\
\hline Sylvilagus brasiliensis (Linnaeus, 1758) & & 9 & 0 \\
\hline \multicolumn{4}{|l|}{ Carnivora } \\
\hline Canis lupus familiaris* Linnaeus, 1758 & & 11 & 17 \\
\hline Cerdocyon thous (Linnaeus, 1766) & & 0 & 11 \\
\hline Chrysocyon brachyurus (Illiger, 1815) & VUBR & 8 & 3 \\
\hline Lycalopex vetulus Lund, 1842 & VUBR & 0 & 13 \\
\hline Nasua nasua (Linnaeus, 1766) & & 0 & 12 \\
\hline Procyon cancrivorus (G.[Baron] Cuvier, 1798) & & 0 & 5 \\
\hline Puma yagouaroundi (É. Geoffroy Saint-Hilaire, 1803) & VUBR & 5 & 0 \\
\hline Leopardus pardalis (Linnaeus, 1758) & & 0 & 7 \\
\hline Puma concolor (Linnaeus, 1771) & VUBR & 3 & 0 \\
\hline Panthera onca (Linnaeus, 1758) & VUBR & 2 & 0 \\
\hline \multicolumn{4}{|l|}{ Perissodactyla } \\
\hline Tapirus terrestris (Linnaeus, 1758) & VUUUCN,BR & 14 & 18 \\
\hline \multicolumn{4}{|l|}{ Artiodactyla } \\
\hline Mazama americana (Erxleben, 1777) & & 7 & 7 \\
\hline Mazama gouazoubira (G. Fischer [von Waldheim], 1814) & & 9 & 8 \\
\hline Ozotoceros bezoarticus (Linnaeus, 1758) & VUBR & 5 & 0 \\
\hline Bos taurus* Linnaeus, 1758 & & 0 & 51 \\
\hline \multicolumn{4}{|l|}{ Rodentia } \\
\hline Hydrochoerus hydrochaeris (Linnaeus, 1766) & & 0 & 4 \\
\hline Cuniculus paca (Linnaeus, 1766) & & 0 & 9 \\
\hline Dasyprocta leporina (Linnaeus, 1758) & & 0 & 7 \\
\hline
\end{tabular}


(SD: 0.92) in the dry season and 23 species (0.96) in rainy season (Fig. 3).

The NMDS result showed that the composition and frequency of records of medium and large mammals in the CVNP differed between dry and rainy seasons (Fig. 4), and the rainy season had a higher species richness and frequency of records with 10 species in the dry season and 19 species in the rainy season (Two-way ANOVA, $F=133,98, p<0,001)$. The composition and the frequency of species records were also different between the interior of the CVNP and its surroundings (Fig. 4), pre- senting a higher richness and frequency of records in the surroundings of the CVNP (Two-way ANOVA, $F=81.81$, $\mathrm{p}<0,001)$.

\section{DISCUSSION}

We found 23 species of native mammals in the CVNP region. The record of Panthera onca in the region was the first using camera-traps in the CVNP. It is worth mentioning that the species was recorded only inside the park. In

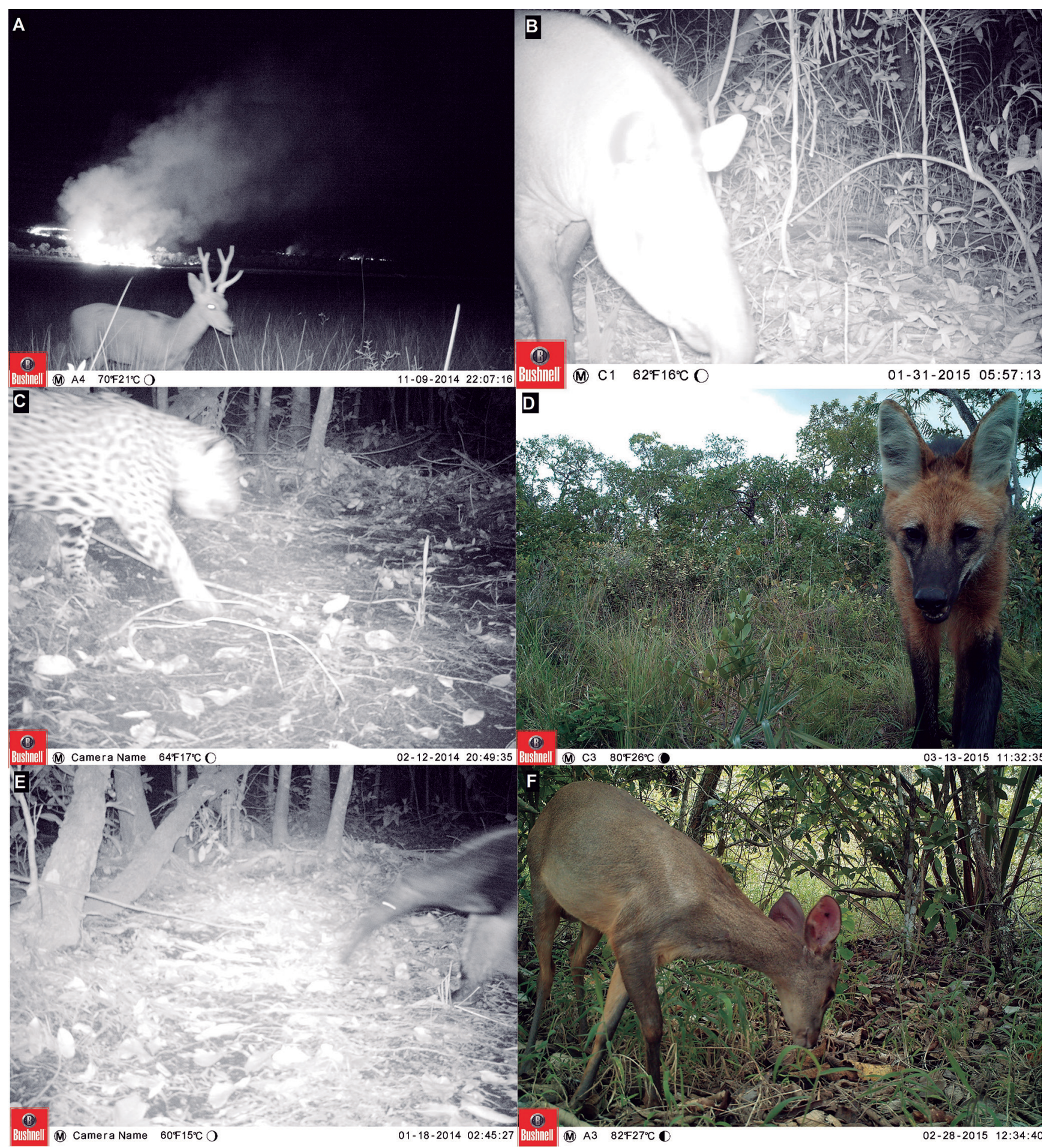

Figure 2. Medium and large-sized mammals recorded in the Chapada dos Veadeiros National Park and surroundings, Goiás, Brazil. (A) Ozotoceros bezoarticus; (B) Tapirus terrestris; (C) Panthera onca; (D) Chrysocyon brachyurus; (E) Myrmecophaga tridactyla; and (F) Mazama gouazoubira. 


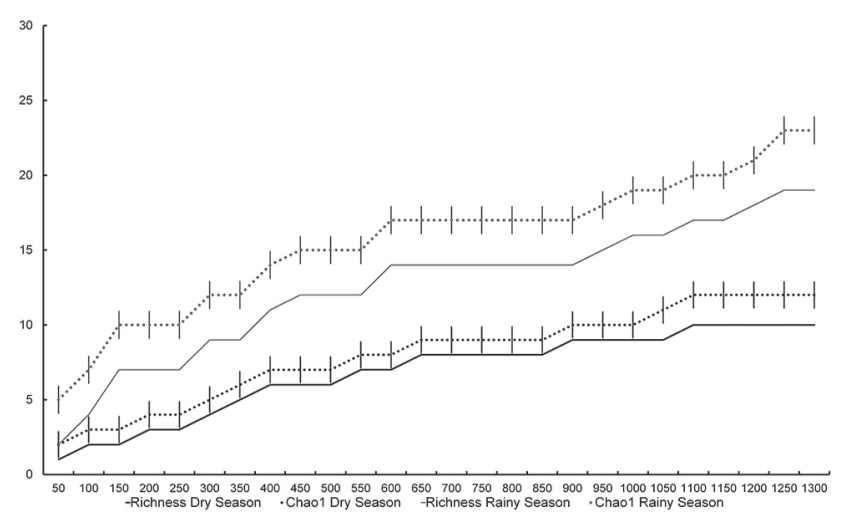

Figure 3. Rarefaction curves of the number of mammalian species recorded in the Chapada dos Veadeiros National Park and its surroundings during the dry and rainy seasons, state of Goiás, central Brazil.

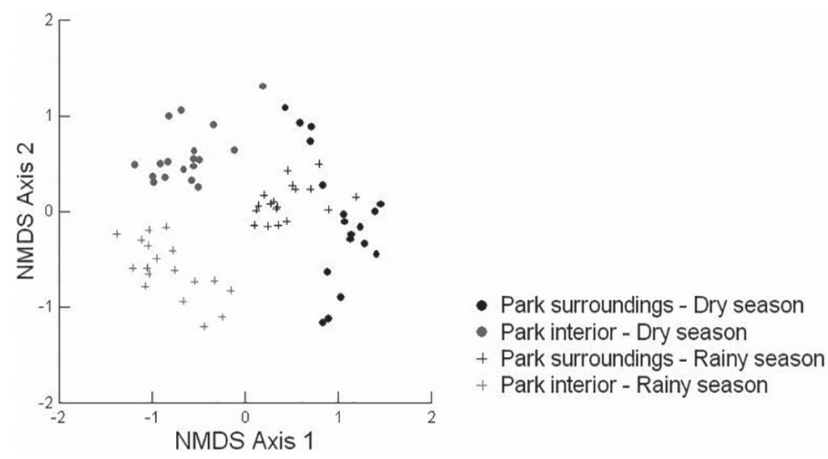

Figure 4. Non-Metric Multidimensional Scaling (NMDS) with Bray-Curtis distance matrix between the frequencies of mammalian registered in each camera trap located in the Chapada dos Veadeiros National Park, state of Goiás, central Brazil.

addition, we observe, according to the rarefaction curve as a function of the camera-days effort (Fig. 3), that during the rainy season there is an increase in recording new species, and during the dry season the curve tends to stabilize with smaller values of new species. This study showed a similar species richness compared to other inventories in the Cerrado and the presence of endangered species (i.e., nine species) is also noteworthy. In Goiás, other studies with medium and large sized mammals had previously recorded 23 species from the Silvânia National Forest (Campos et al., 2013) and 28 species in Emas National Park (Silveira et al., 2003), both in protected areas.

The sampling methods used were effective for recording the species and showed evidence of a high species richness in this study. Camera trapping was demonstrated to be the most effective methods to detect mammals (Goulart et al., 2009; Ferreguetti et al., 2017). According to Silveira et al. (2003), camera trapping is the most appropriate method for mammal inventory in all environmental conditions.

The richness was different between the areas sampled within the CVNP and in its surroundings with higher richness in the surrounding zone of the CVNP. We did not corroborate the hypothesis about the higher richness in the sites within of CVNP. One of the factors that can explain this difference is the type of vegetation cover of each of these two areas sampled. In total, the CVNP presents $77 \%$ of savanna formation and $9 \%$ corresponds to the forest fragments (Porto et al., 2011). On the other hand, the CVNP surroundings have the largest sum of private reserves (Private Reserves of Natural Heritage - RPPN) of the State of Goiás, totaling 21 RPPNs with $21,515.87$ ha (30\% of CVNP area) and these areas hold a high percentage of forest cover (Falconi \& Diniz-Filho, 2003; Silva et al., 2016). About $80 \%$ of the RPPNs area, located in the Alto Paraíso region, are protected near the sampling areas in this study (Silva et al., 2016). This higher richness corroborates with the studies that indicate the importance of the surroundings of the CVNP as a buffer zone of the anthropic impacts (Silva et al., 2016). It is possible that the vegetation type mosaic in the CVNP surroundings contributed to the higher mammal richness found in the present study, because the large-sized mammal species need larger areas for foraging and diversified environments to explore a large resource variety (Lyra-Jorge et al., 2008; Brady et al., 2011).

Common species such as Cuniculus paca, Dasyprocta leporina, Sapajus nigritus and Dasypus novemcintus, which are abundant in forest areas, had a high frequency of records in these surroundings areas (Table 1). Although these species can increase the richness of species, rare species such as Myrmecophaga tridactyla and Chrysocyon brachyurus were also found in the CVNP surroundings but had a smaller frequency of records when compared to the areas located within the CVNP. Even without considering the conservation value of the species (i.e., rare and endangered species) found in the surroundings, the forest regions present important habitat suitability characteristics for certain species of medium- and large-sized mammals (Klink \& Machado, 2005). The highest number of species and records were found in the camera-traps located in forest areas located in both areas, confirming studies that demonstrate the importance of forest vegetation types for the conservation of the Cerrado (Alho, 1981; Bonvicino et al., 2005). Other factors, especially anthropic pressures (suppression of vegetation, burning, increased tourism, paving of roads and the presence of exotic species such as domestic dogs and cattle) need to be better studied in the region urgently, to verify how these factors are affecting the different species. It is necessary to map with higher accuracy as the anthropic effects may be influencing the difference of richness within the CVNP and in its surroundings.

In addition to the native species, we also recorded domestic ones which are recognized as disease vectors and as predators of wild animals (Lessa et al., 2016). Dogs (Canis familiaris) is the domestic animal considered to be the most common and widespread invasive exotic species worldwide, living in intense association with humans (Vanak \& Gompper, 2009; Hughes \& Macdonald, 2013; Lessa et al., 2016). Futhermore, we recorded the presence of Bos taurus in the surrounding area of the CVNP. The impacts related to this species mainly consists of the deforestation of native areas for the creation of pasture for the species (Durigan et al., 2007). It is necessary to verify the impacts that the cattle causes, mainly because the presence of this species can remarkably change the 
structure and dynamics of the Cerrado vegetation, by selective herbivory and mechanical impact (Souza et al., 2006). Every change in land use around natural areas brings its own consequences to the ecosystem, and yet this relationship has rarely been studied. Such threats require special attention, particularly for the nine species regarded as endangered by the IUCN and Brazilian lists (IUCN, 2018; ICMBio, 2018).

Our results also indicate the relevance of long-term water availability when designing protected areas to ensure habitat quality for mammal species, especially in environments with marked seasonality such as the Cerrado. The CVNP and its surroundings contribute to the conservation of endangered species, but a population study is needed to verify the conservation status of these species in a more refined way. Therefore, more attention should be given to the monitoring of these species in the long term because this area still harbor some viable populations of large mammals, highlighting the importance of CVNP for the conservation.

\section{ACKNOWLEDGMENTS}

ICML thanks CAPES for the doctoral scholarship financing this study. To the Biodiversity and Protected Area Laboratory of the Ecology Department, University of Brasilia; the Mammal Ecology Laboratory of the Rio de Janeiro State University (UERJ) and Instituto Chico Mendes de Conservação da Biodiversidade for the permit under SISBIO \#39768-1.

\section{REFERENCES}

Aguiar, L.M.S.; Machado, R.B. \& Marinho-Filho, J. 2004. A diversidade biológica do Cerrado. In: Aguiar, L.M.S. \& Camargo, A. (Eds.). Ecologia e caracterização do Cerrado. Planaltina, Empresa Brasileira de Pesquisa Agropecuária (Embrapa Cerrados). p. 19-42.

Ahumada, J.A.; Silva, C.E.; Gajapersad, K.; Hallam, C.; Hurtado, J.; Martin, E.; McWilliam, A.; Mugerwa, B.; O'Brien, T.; Rovero, F.; Sheil, D.; Spironello, W.R.; Winarni, N. \& Andelman, S.J. 2011. Community structure and diversity of tropical forest mammals: data from a global camera trap network. Philosophical Transactions of the Royal Society B: Biological Sciences, 366(1578): 2703-2711.

Alho, C.J.R. 1981. Small mammal populations of Brazilian Cerrado: the dependence of abundance and diversity on habitat complexity. Brazilian Journal of Biology, 41(1): 223-230.

Barbosa, L.G.M. 2008. Estudo de competitividade dos 65 destinos indutores do desenvolvimento turístico regional - Relatório Brasil. 2. ed. revisada. Brasília, Ministério do Turismo.

Bonvicino, C.R.; Lemos, B. \& Weksler, M. 2005. Small mammals of Chapada dos Veadeiros National Park (Cerrado of Central Brazil): ecologic, karyologic, and taxonomic considerations. Brazilian Journal of Biology, 65(3):395-406.

Brady, M.J.; McAlpine, C.A.; Possingham, H.P.; Miller, C.J. \& Baxter, G.S. 2011. Matrix is important for mammals in landscapes with small amounts of native forest habitat. Landscape Ecology, 26: 617-628.

Campos, F.S.; Lage, A.R.B. \& Ribeiro, P.H.P. 2013. Diversity of medium and large sized mammals in a Cerrado fragment of central Brazil. Journal of Threatened Taxa, 5(15): 4994-5001.
Chiarello, A.G. 1999. Effects of fragmentation of the Atlantic forest on mammal communities in south-eastern Brazil. Biological Conservation, 89(1): 71-82.

Colwell, R.K. 2013. EstimateS: Statistical estimation of species richness and shared species from samples. Version 9.0. Available at: http://purl.oclc. org/estimates Google Scholar.

Costa, L.P. 2003. The historical bridge between the Amazon and the Atlantic Forest of Brazil: a study of molecular phylogeography with small mammals. Journal of Biogeography, 30(1): 71-86.

Costa, L.P.; Leite, Y.L.R.; Mendes, S.L. \& Ditchfield, A.D. 2005. Mammal conservation in Brazil. Conservation Biology, 19(3): 672-679.

Drummond, J.A.; de Andrade Franco, J.L. \& Ninis, A.B. 2009. Brazilian federal conservation units: a historical overview of their creation and of their current status. Environment and History, 15(4): 463-491.

Durigan, G.; Siqueira, M.F.D. \& Franco, G.A.D.C. 2007. Threats to the Cerrado remnants of the state of São Paulo, Brazil. Scientia Agricola, 64(4): 355-363.

Eisenberg, J. \& Redford, K. 1999. Mammals of the neotropics, Vol. 3. The central neotropics. Chicago, University of Chicago Press.

Eiten, G. 1972. The cerrado vegetation of Brazil. The Botanical Review, 38(2): 201-341.

Falconi, L.C. \& Diniz-Filho, J.A.F. 2003. A evolução temporal e espacial das reservas particulares do patrimônio natural no Estado de Goiás de 1990 a 2002. Revista Estudos - Vida e Saúde. Goiânia, 30(9): 1983-2284.

Felfili, J.M.; Nascimento, A.R.T.; Fagg, C.W. \& Meirelles, E.M. 2007. Floristic composition and community structure of a seasonally deciduous forest on limestone outcrops in Central Brazil. Brazilian Journal of Botany, 30(4): 611-621.

Ferreguetti, A.C.; Tomas, W.M. \& Bergallo, H.G. 2017. Differences in the mammalian habitat use in a mosaic of vegetation types of an Atlantic rain-forest reserve, Brazil. Mastozoología neotropical, 24(2): 355-364.

Freitas, I.F. 2009. Unidades de Conservação no Brasil: 0 Plano Estratégico Nacional de Áreas Protegidas e a viabilização da zona de amortecimento. Master dissertation. Campinas, SP., Universidade Estadual de Campinas - UNICAMP.

Galetti, M.; Bovendorp, R.S. \& Guevara, R. 2015. Defaunation of large mammals leads to an increase in seed predation in the Atlantic forests. Global Ecology and Conservation, 3: 824-830.

Galetti, M.; Giacomini, H.C.; Bueno, R.S.; Bernardo, C.S.; Marques, R.M.; Bovendorp, R.S.; Steffler, C.E.; Rubim, P.; Gobbo, S.K.; Donatti, C.I.; Begotti. R.A.; Meirelles, F.; Nobre, R.A.; Chiarello, A.G. \& Peres, C.A. 2009. Priority areas for the conservation of Atlantic forest large mammals. Biological Conservation, 142(6): 1229-1241.

Goulart, F.V.B.; Cáceres, N.C.; Graipel, M.E.; Tortato, M.A.; Ghizoni Jr., I.R. \& Oliveira-Santos, L.G.R. 2009. Habitat selection by large mammals in a southern Brazilian Atlantic Forest. Mammalian Biology, 74(3): 182-190.

Hughes, J. \& Macdonald, D.W. 2013. A review of the interactions between free-roaming domestic dogs and wildlife. Biological Conservation, 157: 341-351.

Instituto Chico Mendes de Conservação da Biodiversidade (ICMBio). 2018. Livro Vermelho da Fauna Brasileira Ameaçada de Extinção. Mamíferos. Brasília, Editora ICMBio/MMA. v. 2, 625p.

International Union for Conservation of Nature (IUCN). 2018. The IUCN Red List of threatened species version 2018.4. Available at: http://www. iucnredlist.org. Access in: 07/07/2019.

Johnson, M.A.; Saraiva, P.M. \& Coelho, D. 1999. The role of gallery forests in the distribution of Cerrado mammals. Revista Brasileira de Biologia, 59(3): 421-427.

Klink, C.A. \& Machado, R.B. 2005. Conservation of the Brazilian cerrado. Conservation biology, 19(3): 707-713. 
Le Saout, S.; Hoffmann, M.; Shi, Y.; Hughes, A.; Bernard, C.; Brooks, T.M.; Bertzky, B.; Butchart, S.H.M.; Stuart, S.N.; Badman, T. \& Rodrigues, A.S. 2013. Protected areas and effective biodiversity conservation. Science, 342(6160): 803-805.

Lessa, I.; Guimarães, T.C.S.; de Godoy Bergallo, H.; Cunha, A. \& Vieira, E.M. 2016. Domestic dogs in protected areas: a threat to Brazilian mammals? Natureza \& Conservação, 14(2): 46-56.

Lessa, I.C.M.; Ferreguetti, Á.C.; Kajin, M.; Dickman, C.R. \& Bergallo, H.G. 2017. You can't run but you can hide: the negative influence of human presence on mid-sized mammals on an Atlantic island. Journal of Coastal Conservation, 21(6): 829-836.

Lyra-Jorge, M.C.; Ciocheti, G.; Pivello, V.R. \& Meirelles, S.T. 2008. Comparing methods for sampling large-and medium-sized mammals: camera traps and track plots. European Journal of Wildlife Research, 54(4): 739.

Marcuzzo, F.F.N.; Cardoso, M.R.D. \& Faria, T.G. 2012. Chuvas no cerrado da região centro-oeste do Brasil: análise histórica e tendência futura. Ateliê Geográfico, 6(2): 112-130.

Mittermeier, R.A.; Fonseca, G.D.; Rylands, A.B. \& Brandon, K. 2005. Uma breve história da conservação da biodiversidade no Brasil. Megadiversidade, 1(1): 14-21.

Myers, N.; Mittermeier, R.A.; Mittermeier, C.G.; Da Fonseca, G.A. \& Kent, J. 2000. Biodiversity hotspots for conservation priorities. Nature, 403(6772): 853

Noguera-Urbano, E.A. \& Escalante, T. 2015. Áreas de endemismo de los mamíferos (Mammalia) neotropicales. Acta Biológica Colombiana, 20(3): 47-65.

O'Connell, M.A. 1989. Population dynamics of neotropical small mammals in seasonal habitats. Journal of Mammalogy, 70(3): 532-548.
Paglia, A.P.; da Fonseca, G.A.B.; Rylands, A.B.; Herrmann, G.; Aguiar, L.M.S.; Chiarello, A.G.; Leite, Y.L.R.; Costa, L.P.; Siciliano, S.; Kierulff, C.M.; Mendes, S.L.; Tavares, V.C.; Mittermeier, R.A. \& Patton, J.L. 2012. Lista Anotada dos Mamíferos do Brasil / Annotated Checklist of Brazilian Mammals. 2.ed. Occasional Papers in Conservation Biology, 6: 76.

Porto, A.C.; Linares, J.A.H. \& Neto, G.B.S. 2011. Análise da estrutura e dinâmica da paisagem do Parque Nacional da Chapada dos Veadeiros. In:Simpósio Brasileiro de Sensoriamento Remoto-SBSR, $15^{\circ}$. Anais. Curitiba, INPE. p. 3057.

Silva, D.C.B.; Segalerba, M.D.B. \& Brandão, R.A. 2016. A representatividade das reservas particulares do patrimônio natural (RPPN) no entorno do Parque Nacional da Chapada dos Veadeiros, estado de Goiás, Brasil. Heringeriana, 9(2): 64-78.

Silveira, L.; Jacomo, A.T. \& Diniz-Filho, J.A.F. 2003. Camera trap, line transect census and track surveys: a comparative evaluation. Biological Conservation, 114(3): 351-355.

Souza, S.C.P.M.; Durigan, G. \& Melo, A.C.G. 2006. Impacto do gado sobre a regeneração do Cerrado em área invadida por braquiária (Urochloa decumbens (Stapf.) R.D. Webster) em Assis, SP. In: Congresso Nacional de Botânica, 57². Anais. Gramado, SBB/UFRGS. CDRom (Resumo 489).

Vanak, A.T. \& Gompper, M.E. 2009. Dogs Canis familiaris as carnivores: their role and function in intraguild competition. Mammal Review, 39(4): 265-283.

Walter, B.M.T. \& Ribeiro, J.F. 2008. 0 conceito de savana e de seu componente Cerrado. Cerrado: Ecologia e Flora. Brasília, DF, Embrapa Informação Tecnológica. p. 19-45.

Wilson, D.E. \& Reeder, D.M. 2005. Mammal species of the world: a taxonomic and geographic reference. Baltimore, John Hopkins University Press. v. 2. 